\title{
Acceptability of Stative Verbs in Progressive Form within Linguistic Context
}

\author{
Imran Muhammad ${ }^{1} \&$ Mamuna Ghani ${ }^{2}$ \\ ${ }^{1}$ Govt. Postgraduate College, Burewala, Pakistan \\ ${ }^{2}$ Department of English, The Islamia University of Bahawalpur, Pakistan \\ Correspondence: Imran Muhammad Govt. Postgraduate College, Burewala, Pakistan. E-mail: \\ imranchuhan@hotmail.com
}

Received: April 10, 2017 Accepted: May 8, 2017 Online Published: July 15, 2017

doi:10.5539/ijel.v7n4p67 URL: http://doi.org/10.5539/ijel.v7n4p67

\begin{abstract}
The controversy over the use of English stative verbs in progressive aspect has vexed the researchers throughout the ages. Traditional grammars see "progressive statives" as highly unacceptable in any context. However, Smiecinska (2002) goes in line with Kakietek (1997) who admits the acceptability of stative verbs in progressive form. The present study reports on a survey conducted among $68 \mathrm{EFL}$ learners of intermediate, bachelor and master's level studying at Govt. Postgraduate College Burewala, Punjab, Pakistan. The main object of the study was to explore the acceptability level of progressive statives. Secondly, this paper focused on examining the extent to which the context of stative verb plays its role in imposing the choice of progressive aspect. For the purpose of data collection, a questionnaire designed by Smiecinska (2002) was used with few changes in it after the pilot study was completed. The findings of the survey went along with those reported in previous studies. The majority of the participants considered the stative verbs in progressive form as acceptable with a wide margin. The results revealed that the higher the study level was, the more acceptability was. However, the study culminated in a perception that aloofness from the grammatical rules invites dependency on the context in choosing aspect for stative verb.
\end{abstract}

Keywords: stative verbs, progressive aspect, grammatical rules, acceptability, context

\section{Introduction and Literature Review}

English verbs are divided into two categories i.e., stative verbs and action verbs. Action verbs are also called dynamic verbs which counterpoint with stative verbs on the ground that the latter does not appear in progressive aspect in general. Imran et al. (2016) report that stative verbs represent indefinite events (with no end point) that befall spontaneously. Traditionally viewed, progressive aspect is closely connected with the semantics of the verbs and is used to express duration and temporary validity of an action. Therefore, over extension of the progressive marker -ing to stative verbs seems rather awkward. But there is a long catalogue of the researchers who advocate the use of both stative and dynamic verbs in progressive aspect. Huddleston \& Pullum (2002), Leech (2004) and Quirk and others (1985) readily accept the use of statives in progressive form. Contrary to them, Comrie (1973), Joos (1964) and Ota (1963) forcibly argue that the lexemes which express unlimited duration can hardly occur in progressive aspect. However, according to Smiecinska (2002), a trend of excessive use of statives in progressive form has been observed during the last decades and Kakietek's (1997) recent study also reveals that stative verbs can freely appear in appropriate contexts. This paper is focused on evaluating the acceptability of "progressive statives" as well as examining the extent to which the context of stative verb plays its role in imposing the choice of progressive aspect.

\subsection{The Progressive Aspect and the Stative Verbs}

According to Quirk and others $(1985$, p. 188) "the term aspect refers to a grammatical category which reflects the way in which the verb action is regarded or experienced with respect to time". Smiecinska (2002) reports that the terms status and stative are used to refer to stative verbs, the latter being probably the most common term used, among others, in Quirk et al. (1972) and Comrie (1976). According to them, stative verbs are used to describe cognitive (know, understand, like, prefer, doubt, believe), emotional (hate, love) and physical (be, have, seem) states of being. The most heterogeneous to dynamic verb is state verb. For example, "I hate quotations. 
Tell me what you know" (Ralph Waldo Emerson), and "The future belongs to those who believe in the beauty of their dreams" (Eleanor Roosevelt). Defining states and occurrences Huddleston \& Pullum (2002, p. 119) state that "states exist or obtain, while occurrences happen, take place". They suggest that states do not go through any change whereas occurrences do. Biber, Conrad \& Leech (2002, p. 456) define the dynamic verbs as verbs which "express action or events", and confine the states to the "verbs which refer to mental states, attitudes/emotions, perceptions, or other states of existence" (p. 460).

As far as aspect is concerned, simple present and present progressive aspect both can indicate the events that will happen in near future. According to Quirk and others (1985, p. 215), present progressive aspect is used to indicate the notion of near future to the human activities or events only as in 'He is dying next week' for his death is already planned for death penalty. They exclude the natural events from this category *'The trees are loosing their leaves soon'.

Quirk and others (1985, p. 200-206) have divided stative verbs into different groups according to the meaning they convey. Leech (2004, p. 25-27) has also propounded a division of verbs but it is not typical for progressive aspect. However, Quirk and others' research necessarily deals with the division of stative verbs. Quirk and others (1985, p. 198-199) are of the view that stative verbs cannot be used in progressive aspect such as own in 'I own /*am owning a big amount of money'. They hold the notion that progressive can occur with some stative verbs which express temporariness as in "I am living in a small flat" rather than permanence as in "I live in a small flat". But this cannot be true in case of all stative verbs. According to them, the use of progressive aspect can be made for the sake of generating politeness or softening. Quirk and others $(1985$, p. 210) proclaim that the progressive form can be used with some statives pointing "tentatively to a present wish or attitude" as in 'I'm hoping to borrow some money'. Add to this Ute Romer (2005, p. 97-98) opines that the absence of progressive in such cases will result in producing aggressiveness. Hence, just, whether and actually are used as adverbials to make the sentences polite. Romer $(2005$, p. 98$)$ stresses the point that such expressions are more common in spoken form than in written form of English as in 'I was just wondering how you'd be paid'.

Moreover, a distinction is made between qualities and states on the basis of stative verbs. Qualities and states are generally expressed by the verbs e.g. be and have. According to Quirk and others (1985, p. 200), qualities are the characteristics of the subject of the sentence, and they are almost permanent whereas the states are less permanent. Qualities never occur with the progressive form whether expressed by be or have as is evident in 'John is / *is being Australian" and "John has /* is having brown eyes'. Hence, both be and have representing states can possibly occur in progressive form but at the same time the meaning undergoes a change. The sentence "John is / is being awkward" in simple present form expresses the personality trait and in progressive form implies the present behavior. Similarly, in 'John has / is having a cold', the progressive form shows a deliberate state, meaning thereby "pretention of illness". (Quirk et al., 1985, p. 200) Leech and Svartvik (2002, p. 77) specify that verb be can also occur in progressive form when it is followed by the noun or adjective. They put forward the sentence 'He is being a hero' as an example in which the stative verb in progressive form refers to some personal behavior or 'the role a person is adopting'.

However, one thing is clear that researchers vary in their approach towards the use of stative verbs in progressive aspect. They are divided into two groups. A group of linguistics casts vote in favour of one approach and the other group contradicts that very idea. Following are the conflicting views that have snatched the similitude among the researchers regarding the aspectual use of statives.

Swan (1995, p. 231) does not favour the concept of using the 'states' in progressive aspect. He is of the opinion that the sentence *I'm having a headache is not acceptable at all. His research of corpora reveals that this expression is being used neither in BrE nor in AmE. Comrie states that "stative verbs do not have progressive forms since this would involve an internal contradiction between the stativity of the verbs and the non stativity essential to the progressive" (1976: p. 35). Contrary to Kakietek's (1997), Zeno Vendler (1967) holds the notion that states are homogeneous and static and have no internal structure which changes over time. Similarly, in his verb typology where states are marked as +statives and process verbs are marked as -statives, Lakoff (1970) sees no difference between semantically stative verbs and syntactically stative verbs. According to him, the sentence 'He is knowing the answer' is ungrammatical because in that +stative is used in -stative. Hirtle (1967) and Quirk et al. (1972) support the idea of stative and dynamic uses of verbs, rather than of stative and dynamic verbs. In fact, Hirtle (1968) wants to say that it is the context that determines the use of progressive or non progressive forms of the verbs whereas Comrie (1973), Joos (1964) and Ota (1963) forcibly argue that the lexemes which express unlimited duration can hardly occur in progressive aspect. Thus, according to them, it is not the context but the semantics of the verb which determines its use in aspectual form. Add to this Ota (1963, p. 113) states that such verbs "denote states, not processes". 
Biber, Conrad \& Leech (2002, p. 163-164) advocate the use of both static and dynamic verbs in progressive aspect. They include bleed and starve in this category of verbs. Huddleston \& Pullum (2002, p. 169) strongly favour the use of statives in progressive aspect but in their agentive form. Quirk and others (1985, p. 203-204) seem to harp on the same string by calling this category as agentive. They exclude see and hear from this category on the ground that these cannot be replaced by the dynamic. They readily accept the stative verbs in their agentive forms look (at) and listen (to) in progressive aspect. According to them, stance verbs can fall in both the categories i.e. stative and dynamic verbs. Quirk et al. (1985, p. 206) argue that the non-progressive form is used in the sentences which refer to a permanent state as in 'The most important building stands near the main road'. Similarly, progressive form seems more suitable in the sentences which refer to a temporary state as in 'She is standing at the bus stop'. Nonetheless, according to Huddleston and Pullum (2002, p. 167), waxing and waning situation has power to change the meaning of stative verbs. For example, Resemble in simple present tense indicates the state of appearance as in 'She resembles her grandmother' whereas the same in present progressive form expresses the increase in resemblance as in 'She is resembling his grandmother more and more every year'. Leech $(2004$, p. 31) advocates the same idea by relating the interpretation of former sentence to 'to be like' and the latter one to 'to become like'. Similarly, the verb in simple present tense in 'She makes mistakes' denotes the repeated event whereas, the same stative verb in progressive form 'She is making fewer and fewer mistakes' conveys the idea that the situation is not constant but improving (waning) gradually. Comrie justifies this use of stative verbs in progressive form by interpreting the meaning in the terms of "a developing process, in which the individual phases are essentially different from one another" (1976, p. 37). Debopam Das (2010) argues that non progressive verbs are not at all forbidden to occur in progressive aspect though it goes in contradiction with set rules adopted by traditional grammars. His findings go in line with Kakietek (1997) and Smiecinska (2002). Scheffer (1975) also analyzed a corpus of several contemporary British and American novels and found myriads of the constructions in which stative verbs were used in progressive aspect.

However, Kakietek's (1997) observation based on the corpus of British and American novels, detective stories, scientific texts and popular dailies and weeklies reveals that the use of stative verbs in the progressive form is increasing in the present day $\mathrm{BrE}$ and $\mathrm{AmE}$. He conducted a study on stative verbs and reached a conclusion that stative verbs can freely occur in progressive aspect in particular contexts and that they do not constitute a separate syntactic category (1997, p. 85). Smiecinska (2002) carries out a survey in order to investigate the acceptability of progressive form in stative verbs among the students of Slippery Rock University, USA and reaches a conclusion that there is a strong tendency among the young native speakers to accept progressive statives in appropriate contexts.

To verify the validity of Kakietek's postulations and Smiecinska's conclusions, and so, to check to what extent the use of stative verbs in progressive form counts on appropriate context, a survey was conducted among young EFL learners in Pakistan. The details of the study are as follows.

\section{Research Methodology}

A survey was carried out in March 2017 in Burewala, Punjab, Pakistan among the students (EFL learners of intermediate, bachelor and master's level) of Govt. Postgraduate College.

\subsection{The Questionnaire}

A questionnaire designed by Smiecinska (2002) was used to collect the desired data. After the pilot study in which fifteen students participated, three types of changes were brought onto the final questionnaire.

a. Three options replaced with two options (a. right/grammatically correct or b. wrong/grammatically incorrect) were to appear against each sentence item in part one of the questionnaire.

b. Sentence 5 used as distractor was replaced with the following regular sentence:

Their house was facing the skating rink when I looked from the threshold.

c. Three sentences $(4,16,20)$ used in Smiecinska's questionnaire were replaced with the following new ones:

Sentence 4: Rotten onions were smelling bad.

Sentence 16: The road ........ here. a). is ending b). ends

Sentence 20: This offer ............ on Monday evening. a). is closing b). closes

The rest of the questionnaire was used as same. However, Smiecinska (2002) examined a long catalogue provided by Scheffer (1975), of 140 verbs marked as stative verbs in their basic meanings in several grammar handbooks by Joos (1964), Jaspersen (1931), Quirk et al. (1972) and Hornby (1954). He selected 30 stative verbs 
authenticated by the majority of the authors. Out of those thirty verbs, 14 were carefully chosen keeping in view their frequency of use in Brown Corpus and Collins Cobuild Corpus of spoken English. 20 sentences were composed out of these fourteen stative verbs. Each stative verb was put in progressive aspect. The verbs he used in his survey were: appear, believe, cost, doubt, hate, hear, intend, know, like, look, see, understand and want.

Nevertheless, the questionnaire finalized for the present study had two parts with twenty sentences in toto. Part one included eleven sentences among which the sentences (1), (2), and (8) were chosen as distractors. The participants were asked to mark one of the two options i.e., a) right/grammatically correct or b) wrong/grammatically incorrect. They were instructed to encircle the part of the sentence rendering it ungrammatical. Among the distracting sentences, sentence (1) was grammatically correct, posing no problem, sentence (2) exhibited concord violation and sentence (8) contained double negation.

Part II of the questionnaire consisted of nine sentences. Blanks were left to be filled in by choosing one of the two options i.e., (a) or (b) with each representing either simple verb form or progressive verb form given alternatively against each sentence.

\subsection{Procedure}

A questionnaire comprising on 17 reliable sentences (exclusive of three distractors) was distributed among $(\mathrm{N}=68)$ EFL learners of Intermediate, Bachelor and Master's level studying at Govt. Postgraduate College Burewala, Punjab, Pakistan. 22 science students of intermediate level, 29 students from B.Sc and 17 students from M.A. (English Language and Literature) class participated in the present study. In order to develop participants' interest and to gather data, they were asked to add their names and levels of study. The participants from Intermediate and Bachelor levels were male students and those from master's level were females, all aged from 17 to 23, more proficient in writing skill than in speaking skill. So, the flexibility in the spoken form of English language was no more a hindrance in their way to fill out the questionnaire, but the possibility of the influence of GTM (Grammar Translation Method) seemed natural in their choice of options. Meaning thereby, the semantics of the verb in its use in aspectual form was observable. The findings of the distracters were not included in the results. To reach the results, the formula of percentage was applied.

\section{Results and Discussion}

Descriptive statistics served the purpose of analyzing the responses to the questionnaire of this research. In both the parts of the questionnaire, the analysis focused on the percentage of option (a) to find out the acceptability ratings and option (b) to get at the unacceptability ratings of using stative verbs in progressive aspect. The outcome of the questionnaire is displayed in Table 1 and Table 2.

Table 1. Acceptable/unacceptable ratings of the sentences at separate levels

\begin{tabular}{lllll}
\hline Study level & Acceptable & Percentage & Unacceptable & Percentage \\
\hline Master's & 180 & $62 \%$ & 109 & $38 \%$ \\
Bachelor & 290 & $59 \%$ & 203 & $41 \%$ \\
Intermediate & 215 & $57 \%$ & 159 & $43 \%$ \\
\hline
\end{tabular}

It follows from the data that the higher the level of participants was, the more they accepted stative verbs in progressive aspect. It means that the role of context is very much there in building up the acceptability level of progressive statives. Table 2 expounds the average percentage of acceptability and unacceptability of the use of stative verbs in progressive form among the participants. It is evident from the findings that the participants' tendency of acceptability outstripped their tendency of unacceptability. 
Table 2. Average acceptable/unacceptable ratings of the sentences one through twenty

\begin{tabular}{lllll}
\hline Sentence Number & Acceptable & Percentage & Unacceptable & Percentage \\
\hline 1 & - & - & - & - \\
2 & - & - & - & - \\
3 & 42 & $62 \%$ & 26 & $38 \%$ \\
4 & 50 & $74 \%$ & 18 & $26 \%$ \\
5 & 56 & $82 \%$ & 12 & $18 \%$ \\
6 & 54 & $79 \%$ & 14 & $21 \%$ \\
7 & 55 & $81 \%$ & 13 & $19 \%$ \\
8 & - & - & - & - \\
9 & 42 & $62 \%$ & 26 & $38 \%$ \\
10 & 43 & $63 \%$ & 25 & $37 \%$ \\
11 & 48 & $71 \%$ & 20 & $29 \%$ \\
12 & 24 & $35 \%$ & 44 & $65 \%$ \\
13 & 38 & $56 \%$ & 30 & $44 \%$ \\
14 & 32 & $32 \%$ & 36 & $68 \%$ \\
15 & 33 & $49 \%$ & 35 & $51 \%$ \\
16 & 16 & $24 \%$ & 52 & $76 \%$ \\
17 & 26 & $38 \%$ & 42 & $62 \%$ \\
18 & 39 & $57 \%$ & 29 & $43 \%$ \\
19 & 31 & $46 \%$ & 37 & $54 \%$ \\
20 & 56 & $82 \%$ & 12 & $18 \%$ \\
\hline Total & 685 & $59 \%$ & 471 & $41 \%$ \\
\hline
\end{tabular}

Table 1 expresses the acceptability and unacceptability ratings of the sentences at three levels i.e., intermediate, bachelor and master. The statistical analysis shows that acceptability level among the participants of master's level stood at $62 \%$ which was greater by 3\% than those at bachelor level. The former was greater by $5 \%$ and the latter was greater by $2 \%$ than those at intermediate level. The level of acceptability seems directly proportional to the level of study inasmuch as the level of acceptability gradually decreased as the level of study descended. Likewise, the level of acceptability gradually increased as the level of study ascended. Thus, the results of present study can be presented in the following numerical form:

$$
\text { Level of acceptability } \propto \text { Level of study }
$$

However, the participants were the followers of grammar translation method which demands the observation of grammatical rules at all levels. Though the participants of higher level outmanoeuvred their juniors in acceptability ratings respectively yet there was an implication that they were more inefficient in observing the rules. Hence, participants' aloofness from the grammatical rules invited their dependency on the context in their choosing aspect for stative verb. Consequently, the level of study stood directly proportional to the dependency on the context. If the level of acceptability is directly proportional to the level of study and the latter is directly proportional to the dependency on the context, there is an implication that the level of acceptability is, in a sense directly proportional to the dependency on the context which can be described in the following numerical form:

$$
\text { Level of acceptability } \propto \text { Dependency on the context }
$$

Mohammad Falhasiri et al. (2012) conducted a similar study among 70 EFL learners aged from 15 to 25 studying at Iran Language Institute (Isfahan branch). They included even 10 native speakers in their study to find out the acceptability level of stative verbs in progressive form. After analyzing the results of all the groups they reach a conclusion that the higher the level of participants is, the more they accept the progressive form as unacceptable. It means that the acceptability level in their study is inversely proportional to the level of study. Hence, the results of their study go contrary to those drawn in the present study.

The empirical data in Table 2 demonstrates that the respondents had a strong tendency of accepting stative verbs in progressive form as the average percentage of acceptability remained 59\% against the paltry percentage of unacceptability. They seemed to be depending more on the context than the semantics of stative verb in choosing appropriate aspect of tense. Their dependency on the appropriate context, in which the verb was used, entailed their choice of progressive aspect. Same survey was carried out by (Smiecinska, 2002) with intrinsically same results in which the participants were the native speakers, the students of Slippery Rock University, USA. His results reveal that there is a strong tendency among the young native speakers to accept progressive statives in appropriate contexts. 
Furthermore, it was in six sentences $(4-7,11 \& 20)$ that the acceptability level of progressive statives ranged beyond seventy percent. Similarly, in as many as 10 sentences, the progressive forms outdid their non progressive counterparts. Hence, the average percentage $59 \%$ of acceptability choices clearly reveals that the context played major role in increasing the level of acceptability. It means that majority of the students did not observe rules in making choice between simple aspect and progressive aspect in the perspective of stative verbs. The conclusion of a similar study conducted among the similar population by Imran, Tahira \& Mamuna (2016, p. 128) that "the science students' understanding of noun and state verb is unsatisfactory" discloses why the average percentage of unacceptability fell into decline.

However, it cannot be denied that high average percentage of acceptability was the direct result of the involvement of context owing to deviation from the rules of translation as Imran et al. report about similar population that "they had scanty knowledge of stative verbs" (2016, p. 121).

\section{Conclusion}

It must be said, in view of the data, that stative verbs are acceptable in progressive aspect as far as EFL learners are concerned in Pakistani context and appropriate context seems dependable in the choice of aspect for stative verbs. The results of the present study coincide with Kakietek's postulations and Smiecinska's findings. But, despite the fact that stative verbs occur in progressive form in various corpora, EFL learners efficient in grammatical rules, considered such constructions as ungrammatical how convincing a context might be in which a stative verb was used. Therefore, it cannot be denied that the use of statives in progressive form looks bizarre rather weird. Aloofness from the grammatical rules invites dependency on the context in putting stative verbs in progressive aspect.

Nevertheless, EFL learners inefficient in grammatical rules forcibly depend upon appropriate context in which a stative verb is used and in turn, the tendency goes in favour of traditionally held views which consider the use of stative verbs in so called progressive aspect as grammatical.

\section{References}

Biber, D., Johansson, S., Leech, G., Conrad, S., \& Finegan, E. (2002). Longman grammar of spoken and written English. Harlow: Longman.

Comrie, B. (1976). Aspect: An introduction to the study of verbal aspect and related problems (Vol. 2). Cambridge University Press.

Das, D. (2010). The uses and distribution of non-progressive verbs in progressive forms: a corpus-based study. In 26th Northwest Linguistics Conference, Vancouver, May (pp. 8-9).

Falhasiri, M., Youhanaee, M., \& Barati, H. (2012). Second Language Acquisition of Progressive Aspect of Stative and Achievement Verbs in English. Journal of Language Teaching and Research, 3(5), 992-1003.

Hirtle, W. (1967). The Simple and the Progressive forms. Quebeck: Les press de Universite Laval.

Hornby, A. (1954). A guide to Pattern in Usage in English. London: Oxford University Press.

Huddleston, R., \& Pullum, G. K. (2002). The Cambridge Grammar of English Language. Cambridge: Cambridge University Press, 1-23.

Imran, M., Asgher, T., \& Ghani, M. (2016). A Study on Science Students' Understanding of Three Lemmas: State Verb, Action Verb and Noun in the State Run Colleges in Pakistan. International Journal of English Linguistics, 6(5), 121.

Jaspersen, O. (1931). A modern English grammar. London: George Allen and Unwin Ltd.

Joos, M. (1964). The English Verb. Madison and Milwaukee: The University of Wisconsin Press.

Lakoff, G. (1970). Irregularity in Syntax. New York: Holt, Reinhart-Winston.

Leech, G. (2004). Meaning and the English Verb (3rd ed.). Harlow: Longman.

Leech, G., \& Svartvik, J. (2002). A Communicative Grammar of English (3rd ed.). Harlow: Longman.

Ota, A. (1963). Tense and aspect in present day American English. Tokyo: Kenkyusha.

Quirk, R., Sidney G., Geoffrey L., \& Jan S. (1985). A Comprehensive Grammar of the English Language. New York: Longman.

Romer, U. (2005). Progressives, Patterns, Pedagogy: A Corpus-driven Approach to English Progressive Forms, Functions, and Didactics. Amsterdam: John Benjamins Publishing. https://doi.org/10.1075/scl.18 
Scheffer, J. (1975). The progressive in English. Amsterdam: North Holland.

Smiecinska, J. (2002). Stative Verbs and the Progressive Aspect in English. Poznan Studies in Contemporary Linguistics, 38, 187-195.

Swan, M. (1996). Practical English Usage: International Student's Edition. Oxford: Oxford University Press.

Vendler, Z. (1967). Verbs and times. In Z. Vendler (Ed.), Linguistics in Philosophy. Ithaca: Cornell University Press.

\section{Appendix A}

The questionnaire

Part I.

1. The girl is now a student at a large university.

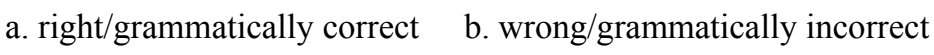

2. She don't know where to go. Help her, please!
a. right/grammatically correct
b. wrong/grammatically incorrect

3. I'm actually liking this play.
a. right/grammatically correct
b. wrong/grammatically incorrect

4. Rotten onions were smelling bad.
a. right/grammatically correct
b. wrong/grammatically incorrect

5. Their house was facing the skating rink when I looked from the threshold.
a. right/grammatically correct
b. wrong/grammatically incorrect

6. I suppose he was hating the scarf and thinking I had no glamour.
a. right/grammatically correct
b. wrong/grammatically incorrect

7. I could not believe what I was hearing. Jody had done the same thing to Lauren that John had done to me.
a. right/grammatically correct
b. wrong/grammatically incorrect

8. They don't know nothing about it, I can assure you.
a. right/grammatically correct
b. wrong/grammatically incorrect

9. I'm understanding Trace theory at last.
a. right/grammatically correct
b. wrong/grammatically incorrect

10. I was seeing him different than when he came first.
a. right/grammatically correct
b. wrong/grammatically incorrect

11. Is she still liking England?
a. right/grammatically correct
b. wrong/grammatically incorrect

Part II.

12. Peter in ghosts in these days.
a). believes
b). is believing

13. Good food more and more now a days.
a). costs
b). is costing

14. Your words, but...
a). am not doubting
b). don't doubt

15. What ..... to do in America before we decided we weren't going there.
a). were you intending
b). did you intend 
16. The road ......... here.
a). is ending
b). ends

17. And while he talked I .. him more and more.
a). was liking
b). liked

18. The grass beautiful, flowers were brilliant.
a). was looking
b). looked

19. But his only response was a slight shake of the hand and almost apologetic expression on his face which indicated to me that he..........
a). did not understand
b). was not understanding

20. This offer on Monday evening.
a). is closing
b). closes

\section{Copyrights}

Copyright for this article is retained by the author(s), with first publication rights granted to the journal.

This is an open-access article distributed under the terms and conditions of the Creative Commons Attribution license (http://creativecommons.org/licenses/by/4.0/). 